\title{
Article \\ Role of Bioaerosols on the Short-Distance Transmission of Multidrug-Resistant Methicillin-Resistant Staphylococcus aureus (MRSA) in a Chicken Farm Environment
}

\author{
Bing-Mu Hsu ${ }^{1,+} \mathbb{D}$, Jung-Sheng Chen ${ }^{2} \mathbb{D}$, Gwo-Jong Hsu ${ }^{3,+}$, Suprokash Koner ${ }^{1,4,+}$, Viji Nagarajan ${ }^{1}$ \\ and Hsin-Chi Tsai ${ }^{5,6, *}$
}

1 Department of Earth and Environmental Sciences, National Chung Cheng University, Chiayi 621, Taiwan; bmhsu@eq.ccu.edu.tw (B.-M.H.); suprokashkoner22@gmail.com (S.K.); mathumitha08@gmail.com (V.N.)

2 Department of Medical Research, E-Da Hospital, Kaohsiung 824, Taiwan; nicky071214@gmail.com

3 Division of Infectious Diseases, Ditmanson Medical Foundation, Chia-Yi Christian Hospital, Chiayi 600, Taiwan; cych01347@gmail.com

4 Department of Biomedical Sciences, National Chung Cheng University, Chiayi 621, Taiwan

5 Department of Psychiatry, School of Medicine, Tzu Chi University, Hualien 970, Taiwan

6 Department of Psychiatry, Tzu Chi General Hospital, Hualien 970, Taiwan

* Correspondence: cssbmw45@gmail.com; Tel.: +886-38561825

+ These authors contributed equally to this work.

\section{check for} updates

Citation: Hsu, B.-M.; Chen, J.-S.; Hsu, G.-J.; Koner, S.; Nagarajan, V.; Tsai,

H.-C. Role of Bioaerosols on the Short-Distance Transmission of Multidrug-Resistant

Methicillin-Resistant Staphylococcus aureus (MRSA) in a Chicken Farm Environment. Antibiotics 2022, 11, 81. https://doi.org/10.3390/antibiotics 11010081

Academic Editor: Ulf Magnusson

Received: 13 November 2021

Accepted: 7 January 2022

Published: 10 January 2022

Publisher's Note: MDPI stays neutral with regard to jurisdictional claims in published maps and institutional affiliations.

Copyright: (C) 2022 by the authors. Licensee MDPI, Basel, Switzerland. This article is an open access article distributed under the terms and conditions of the Creative Commons Attribution (CC BY) license (https:/ / creativecommons.org/licenses/by/ $4.0 /)$.

\begin{abstract}
Methicillin-resistant Staphylococcus aureus (MRSA) is a dynamic and tenacious pathogenic bacterium which is prevalent in livestock farming environments. This study investigated the possibility of MRSA spread via bioaerosol transmission from an indoor chicken farm environment to outdoors downwind (up to $50 \mathrm{~m}$ ). The concentration of total airborne bacteria colony formation units (CFUs) was decreased with increasing sampling distance ranging from $9.18 \times 10^{1}$ to $3.67 \times 10^{3}$ per air volume $\left(\mathrm{m}^{3}\right)$. Among the 21 MRSA isolates, 15 were isolated from indoor chicken sheds and exposure square areas, whereas 6 were isolated from downwind bioaerosol samples. Molecular characterization revealed that all of them carried the staphylococcal cassette chromosome mec (SCCmec) VIII, and they were remarkably linked with the hospital-associated MRSA group. Spa typing analysis determined that all MRSA isolates belonged to spa type t002. Virulence analysis showed that $100 \%$ of total isolates possessed exfoliative toxin A (eta), whereas $38.09 \%$ and $23.80 \%$ strains carried exfoliative toxin B $(e t b)$ and enterotoxin A (ent $A)$. Additionally, all of these MRSA isolates carried multidrug resistance properties and showed their resistance against chloramphenicol, ciprofloxacin, clindamycin, tetracycline, and erythromycin. In addition, chi-squared statistical analysis displayed a significant distributional relationship of gene phenotypes between MRSA isolates from chicken farm indoor and downwind bioaerosol samples. The results of this study revealed that chicken farm indoor air might act as a hotspot of MRSA local community-level outbreak, wherein the short-distance dispersal of MRSA could be supported by bioaerosols.
\end{abstract}

Keywords: methicillin-resistant Staphylococcus aureus (MRSA); bioaerosol transmission; genotyping; antimicrobial resistance; toxins

\section{Introduction}

Antibiotic-resistant strains of Gram-positive pathogens, especially S. aureus, have been isolated from diverse environments such as hospitals, long-term care facilities, rivers, sediments, lakes, soil, and even the deep ocean [1,2]. However, bioaerosol-associated risk related to $S$. aureus remains to be fully understood. The dispersion of microorganisms comprising the pathogenic bacteria associated with bioaerosols can spread in different environments due to their highly aerodynamic properties, such as small diameter and lightweight [3]. Several occupational units (food processing, livestock, waste dumping station, agricultural farmland) and human activities (coughing, sneezing, washroom, and floor 
cleaning) are important sources of bioaerosol formation in the air [4,5]. Kabelitz et al. [6] had mentioned that due to extensive livestock production, the concentration of bioaerosols could increase downwind of farming areas. A better understanding of bioaerosols' functions and the characterization of existing pathogenic microbes could help in estimating the risk of infection in humans and livestock populations by such pathogens [7]. Kim et al. [8] reported that in most zoogenic bacteria and virus-related infectious diseases, such as anthrax, Q-fever, avian and swine influenza, and brucellosis, their severity is propagated via bioaerosol exposure in the environment.

Staphylococcus aureus (S. aureus) is a highly prevalent pathogenic airborne microbe in livestock farming environments [9]. Its severity could increase by acquiring multidrug resistance properties which causes a serious health threat in a host. For example, methicillinresistant S. aureus (MRSA) has enough potential to exhibit nosocomial infections in human and livestock bodies [10]. The surveillance on how MRSA clones are transmitting from one environment to another and their proliferation in a particular area is critical to set up the control strategies against them. Previous studies have shown that the bioaerosols of indoor air in both livestock farming and hospital areas could carry MRSA strains and possibly act as a hotspot for spreading MRSA in the environment [10,11]. MRSA infection was primarily limited to persons directly associated with healthcare facilities with poor immune systems, which is called hospital-acquired MRSA (HA-MRSA) infection [12]. Later on, community-associated MRSA (CA-MRSA) infection was prevalent in healthy people who had never been hospitalized before. Additionally, MRSA strains which are associated with the infection of animal farming and food processing units are described as livestock-associated MRSA (LA-MRSA) [13].

Strain characterization and genotyping are typically required for MRSA epidemiological study. Here, mecA containing the staphylococcal cassette chromosome mec (SCCmec) element is considered a biomarker to identify whether the $S$. aureus strain belongs to MRSA or not [14]. Translation of this mecA gene can produce PBP2a protein (penicillin-binding protein $2 \mathrm{a}$ ), which is mainly responsible for gaining methicillin resistance properties in the $S$. aureus strain [2]. Furthermore, based on the mec and ccr complex sequences in the SCCmec element, it can be classified into I-XI types [2,15]. On the other hand, among different kinds of methods to monitor the epidemiology of MRSA, such as pulsed field gel electrophoresis (PFGE), biotyping, coa typing, prophage typing, multi-locus sequence typing (MLST), spa typing is the most cost-effective, least time consuming, and robust method [15]. The $\mathrm{X}$ region of the spa gene of the MRSA whole genome has been focused to perform spa typing analysis [16]. In addition, the production of various toxin factors such as enterotoxin, exotoxin, and exfoliative toxins (ETs) by MRSA strains has been linked to staphylococcal food poisoning, scalded skin syndrome, and toxic shock syndrome toxin (TSST) [17].

Recently, the MRSA strain has been designated as the most concerning emerging pathogenic threat in different types of livestock farming units, posing a serious health and safety issue for both farmworkers and livestock regarding safe production [18-20]. In this context, our past study identified that bioaerosols of poultry farm indoor air are a suitable carrier of MRSA colonies [11]. However, a detailed view pattern of MRSA strain transmission and distance spread via bioaerosol from poultry farming sources and epidemiology remains unclear $[9,21,22]$. The present study investigated the role of bioaerosol dispersal in transmitting MRSA strains from commercial chicken farm areas to the surrounding environment by using a molecular typing approach. The SCCmec element was amplified for categorization of the isolated MRSA strains. Spa typing was conducted to describe their epidemiology, whereas virulence factors were targeted to identify their pathogenicity. Additionally, an antimicrobial drug resistance test was conducted to evaluate their multidrug resistance pattern. 


\section{Results}

\subsection{Odor Compounds and Airborne Bacteria Load in Chicken Farm Ambient Air}

To obtain the background information on the dispersal of odor compounds in the ambient air from chicken farming practices, the concentrations of ammonia, methylamine, hydrogen sulfide, and mercaptan were estimated for every sampling point. The presence of odor-producing compounds such as ammonia and methylamine were only found in the first and second chicken shed, including the exposure square area of ambient air (Table 1). Ammonia and methylamine concentrations varied between 1.5 and 4.5 ppm and 0.5 and 2.5 ppm per air volume (meter cube), respectively. However, the concentration of such odor-producing compounds was below the detection limit in downwind $(5-50 \mathrm{~m})$ and upwind (up to $-50 \mathrm{~m}$ ) sampling points. The dominant wind was blowing from the north-east and north-west directions of the chicken farm, and the wind speed ranged from 0 to $3 \mathrm{~m} / \mathrm{s}$. The concentration of total airborne bacteria varied from $9.18 \times 10^{1}$ to $3.67 \times 10^{3} \mathrm{CFU}$ per volume air (meter cube) all over the air samples, as shown in Table 1. The indoor air samples from the chicken farm and exposure square had much higher bacteria content $\left(5.75 \times 10^{2}-3.67 \times 10^{3} \mathrm{CFU}\right)$ than the downwind sampling point $\left(9.18 \times 10^{1}-1.40 \times 10^{3} \mathrm{CFU}\right)$. The concentration of airborne bacteria continuously decreased with the increasing distance of sampling points (up to $50 \mathrm{~m}$ ) from the source point (chicken farm). The lowest concentration of airborne bacteria was observed in the upward wind sampling point. In addition, the Pearson correlation coefficient value showed that the concentration of total bacterial CFU had a highly positive correlation $(p=0.01)$ with the concentration of ammonia and methylamine in bioaerosol samples, as shown in Table S3. All of these sampling points carried MRSA in the air, except the $20 \mathrm{~m}$ downwind and $50 \mathrm{~m}$ upwind sampling points. However, bioaerosol samples associated with chicken farm indoor and exposure areas had higher amounts of MRSA. The concentration of MRSA in bioaerosols was decreased with increasing the sampling distance, associated with downwind samples in this order $3>5>50 \mathrm{~m}$.

Table 1. The concentration of odor-producing compounds and the total airborne bacteria in the ambient air.

\begin{tabular}{|c|c|c|c|c|c|c|c|c|}
\hline \multirow{2}{*}{ Sampling Point } & \multicolumn{4}{|c|}{ Concentration of Odor Pollutants (ppm) } & \multirow{2}{*}{$\begin{array}{c}\text { Wind } \\
\text { Direction }\end{array}$} & \multirow{2}{*}{$\begin{array}{c}\text { Wind Speed } \\
(\mathrm{m} / \mathrm{s})\end{array}$} & \multirow{2}{*}{$\begin{array}{c}\begin{array}{c}\text { Total Bacteria } \\
\text { Count }\end{array} \\
\begin{array}{c}\mathrm{CFU} / \mathrm{m}^{3} \\
\text { (by Biostage) }\end{array} \\
\end{array}$} & \multirow{2}{*}{$\begin{array}{c}\text { MRSA } \\
\text { Prevalence }\end{array}$} \\
\hline & Ammonia & Methylamine & $\begin{array}{l}\text { Hydrogen } \\
\text { Sulfide }\end{array}$ & Mercaptan & & & & \\
\hline 1st chicken shed & 3 & 2.5 & $<\mathrm{LOD}$ & $<\mathrm{LOD}$ & North-east & $0.4-0.5$ & $3.67 \times 10^{3}$ & 5 \\
\hline 2nd chicken shed & 4.5 & 2.5 & $<\mathrm{LOD}$ & $<\mathrm{LOD}$ & North-west & $0.5-1.2$ & $3.33 \times 10^{3}$ & 5 \\
\hline Exposure square & 1.5 & 0.5 & $<\mathrm{LOD}$ & $<\mathrm{LOD}$ & South-east & $0-0.4$ & $5.75 \times 10^{2}$ & 5 \\
\hline $3 \mathrm{~m}$ Downwind & $<\mathrm{LOD}$ & $<\mathrm{LOD}$ & $<$ LOD & $<\mathrm{LOD}$ & North-east & $0.9-1.5$ & $1.40 \times 10^{3}$ & 3 \\
\hline $5 \mathrm{~m}$ Downwind & $<\mathrm{LOD}$ & $<\mathrm{LOD}$ & $<\mathrm{LOD}$ & $<\mathrm{LOD}$ & North-east & $0.6-1.0$ & $9.75 \times 10^{2}$ & 2 \\
\hline $20 \mathrm{~m}$ Downwind & $<\mathrm{LOD}$ & $<\mathrm{LOD}$ & $<\mathrm{LOD}$ & $<\mathrm{LOD}$ & South-west & $1.4-1.6$ & $3.03 \times 10^{2}$ & ND \\
\hline $50 \mathrm{~m}$ Downwind & $<\mathrm{LOD}$ & $<\mathrm{LOD}$ & $<\mathrm{LOD}$ & $<\mathrm{LOD}$ & South-east & $0.6-1.4$ & $2.89 \times 10^{2}$ & 1 \\
\hline 50 m Upwind & $<\mathrm{LOD}$ & $<\mathrm{LOD}$ & $<\mathrm{LOD}$ & $<\mathrm{LOD}$ & North-west & $2.4-3$ & $9.18 \times 10^{1}$ & ND \\
\hline
\end{tabular}

LOD $=$ lower than detection limit (ammonia $\leq 0.5 \mathrm{ppm}$, hydrogen sulfide $\leq 0.05 \mathrm{ppm}$, methylamine $\leq 0.01 \mathrm{ppm}$, mercaptan $=0.01 \mathrm{ppm}$ ); ND = not detected (sample has no MRSA isolates).

\subsection{Occurrence of SCCmec Bearing MRSA Clone Bearing and Their Spa Typing in Bioaerosol Samples}

A total of 21 pure MRSA isolates were isolated from bioaerosol samples associated with the majority of sampling points, except for the $20 \mathrm{~m}$ downwind and $50 \mathrm{~m}$ upwind sampling point. All the MRSA isolates and their Id numbers are shown in Table 2. The bioaerosol samples from the chicken shed indoor air and exposure area carried 15 MRSA isolates, where 3, 5 and $50 \mathrm{~m}$ downwind samples carried 3, 2, and 1 isolates, respectively. However, strain categorization revealed that all of these isolates carried the SCCmec element type VIII and belonged to the hospital-associated MRSA group. Additionally, none of them carried the PVL gene. The Spa typing analysis further revealed that these isolates belonged to one spa type (t0002). The chi-squared test score demonstrated that all the isolated MRSA isolates from different sampling points were associated with each other in terms of SCCmec 
typing, spa typing and belonged to the hospital-associated MRSA group, as shown in Table S5.

Table 2. SCCmec and spa typing outcome of MRSA isolates.

\begin{tabular}{|c|c|c|c|c|c|c|}
\hline \multirow{2}{*}{ Sampling Point } & \multirow{2}{*}{$\begin{array}{l}\text { MRSA Isolates } \\
\text { Number }\end{array}$} & \multirow{2}{*}{$\begin{array}{c}\text { MRSA Isolates } \\
\text { ID }\end{array}$} & \multicolumn{3}{|c|}{ SCCmec Typing } & \multirow{2}{*}{ Spa Typing } \\
\hline & & & SCCmec & PVL & HA, CA, LA & \\
\hline \multirow{5}{*}{ 1st chicken shed } & 1 & JCYB101 & VIII & - & HA & t002 \\
\hline & 2 & JCYB102 & VIII & - & $\mathrm{HA}$ & t002 \\
\hline & 3 & JCYB103 & VIII & - & $\mathrm{HA}$ & t002 \\
\hline & 4 & JCYB104 & VIII & - & $\mathrm{HA}$ & t002 \\
\hline & 5 & JCYB105 & VIII & - & HA & t002 \\
\hline \multirow{5}{*}{ 2nd chicken shed } & 6 & JCYB201 & VIII & - & HA & t002 \\
\hline & 7 & JCYB202 & VIII & - & $\mathrm{HA}$ & t002 \\
\hline & 8 & JCYB203 & VIII & - & HA & t002 \\
\hline & 9 & JCYB204 & VIII & - & $\mathrm{HA}$ & t002 \\
\hline & 10 & JCYB205 & VIII & - & $\mathrm{HA}$ & t002 \\
\hline \multirow{5}{*}{ Exposure square } & 11 & JCYB301 & VIII & - & $\mathrm{HA}$ & t002 \\
\hline & 12 & JCYB302 & VIII & - & $\mathrm{HA}$ & t002 \\
\hline & 13 & JCYB303 & VIII & - & HA & t002 \\
\hline & 14 & JCYB304 & VIII & - & $\mathrm{HA}$ & t002 \\
\hline & 15 & JCYB305 & VIII & - & HA & $\mathrm{t} 002$ \\
\hline \multirow{3}{*}{$3 \mathrm{~m}$ Downwind } & 16 & JCYB401 & VIII & - & $\mathrm{HA}$ & t002 \\
\hline & 17 & JCYB402 & VIII & - & $\mathrm{HA}$ & t002 \\
\hline & 18 & JCYB403 & VIII & - & $\mathrm{HA}$ & t002 \\
\hline \multirow{2}{*}{5 m Downwind } & 19 & JCYB501 & VIII & - & HA & t002 \\
\hline & 20 & JCYB502 & VIII & - & HA & t002 \\
\hline $20 \mathrm{~m}$ Downwind & ND & ND & ND & ND & ND & ND \\
\hline $50 \mathrm{~m}$ Downwind & 21 & JCYB701 & VIII & - & HA & t002 \\
\hline $50 \mathrm{~m}$ Upwind & ND & $\mathrm{ND}$ & ND & ND & $\mathrm{ND}$ & ND \\
\hline
\end{tabular}

$\mathrm{ND}=$ not detected (sample has no MRSA isolates).

\subsection{The Profiling of Virulence Factor Encoding Genes for Isolated MRSA Clones}

The virulence-factor-associated genes profiling result showed that $23.80 \%$ and $100 \%$ of total MRSA isolates from chicken farm environment bioaerosol samples carried enterotoxin gene ent $A$ and exfoliative toxin gene eta, as shown in Tables 3 and 4 . In contrast, 38.09\% of isolates carried the exfoliative toxin gene $e t b$. However, none of them carried exotoxin genes such as tsst-1. The exfoliative toxin gene $e t b$ was mostly found in the isolates from chicken shed 2 and the exposure square. In the case of enterotoxin gene ent $A$, this was mainly identified from the exposure square and downwind $(3,5$ and $50 \mathrm{~m})$ distance sampling point MRSA isolates. The exfoliative toxin gene eta was found in all the isolated MRSA clones from each sampling point of this study.

Table 3. Virulence factors profiling results of MRSA isolates.

\begin{tabular}{|c|c|c|c|c|c|c|c|c|c|}
\hline \multirow{2}{*}{$\begin{array}{l}\text { Virulence } \\
\text { Factors }\end{array}$} & $\begin{array}{l}\text { 1st Chicken } \\
\text { Shed }\end{array}$ & $\begin{array}{l}\text { 2nd Chicken } \\
\text { Shed }\end{array}$ & $\begin{array}{l}\text { Exposure } \\
\text { Square }\end{array}$ & $\begin{array}{c}3 \mathrm{~m} \\
\text { Downwind }\end{array}$ & $\begin{array}{c}5 \mathrm{~m} \\
\text { Downwind }\end{array}$ & $\begin{array}{c}20 \mathrm{~m} \\
\text { Downwind }\end{array}$ & $\begin{array}{c}50 \mathrm{~m} \\
\text { Downwind }\end{array}$ & 50m Upwind & $\begin{array}{c}\text { Overall } \\
\text { Detection Rate } \\
(\%)\end{array}$ \\
\hline & $\begin{array}{c}\text { MRSA } \\
\text { Isolates }(n=5)\end{array}$ & $\begin{array}{c}\text { MRSA } \\
\text { Isolates }(n=5)\end{array}$ & $\begin{array}{c}\text { MRSA } \\
\text { Isolates }(n=5)\end{array}$ & $\begin{array}{c}\text { MRSA } \\
\text { Isolates }(n=3)\end{array}$ & $\begin{array}{c}\text { MRSA } \\
\text { Isolates }(n=2)\end{array}$ & $\begin{array}{c}\text { MRSA } \\
\text { Isolates }(n=0)\end{array}$ & $\begin{array}{c}\text { MRSA } \\
\text { Isolates }(n=1)\end{array}$ & $\begin{array}{c}\text { MRSA } \\
\text { Isolates }(n=0)\end{array}$ & $\begin{array}{c}\text { Total MRSA } \\
\text { Isolates }(n=21)\end{array}$ \\
\hline ent $A$ & $(0 \backslash 5)$ & $(0 \backslash 5)$ & $(1 \backslash 5)$ & $(2 \backslash 3)$ & $(2 \backslash 2)$ & ND & $(1 \backslash 1)$ & ND & $23.80 \%$ \\
\hline entB & $(0 \backslash 5)$ & $(0 \backslash 5)$ & $(0 \backslash 5)$ & $(0 \backslash 3)$ & $(0 \backslash 2)$ & ND & $(0 \backslash 1)$ & ND & $0 \%$ \\
\hline entC & $(0 \backslash 5)$ & $(0 \backslash 5)$ & $(0 \backslash 5)$ & $(0 \backslash 3)$ & $(0 \backslash 2)$ & ND & $(0 \backslash 1)$ & ND & $0 \%$ \\
\hline entD & $(0 \backslash 5)$ & $(0 \backslash 5)$ & $(0 \backslash 5)$ & $(0 \backslash 3)$ & $(0 \backslash 2)$ & ND & $(0 \backslash 1)$ & ND & $0 \%$ \\
\hline entE & $(0 \backslash 5)$ & $(0 \backslash 5)$ & $(0 \backslash 5)$ & $(0 \backslash 3)$ & $(0 \backslash 2)$ & ND & $(0 \backslash 1)$ & ND & $0 \%$ \\
\hline eta & $(5 \backslash 5)$ & $(5 \backslash 5)$ & $(5 \backslash 5)$ & $(3 \backslash 3)$ & $(2 \backslash 2)$ & ND & $(1 \backslash 1)$ & ND & $100 \%$ \\
\hline$e t b$ & $(0 \backslash 5)$ & $(4 \backslash 5)$ & $(4 \backslash 5)$ & $(0 \backslash 3)$ & $(0 \backslash 2)$ & ND & $(0 \backslash 1)$ & ND & $38.09 \%$ \\
\hline tsst -1 & $(0 \backslash 5)$ & $(0 \backslash 5)$ & $(0 \backslash 5)$ & $(0 \backslash 3)$ & $(0 \backslash 2)$ & ND & $(0 \backslash 1)$ & ND & $0 \%$ \\
\hline
\end{tabular}


Table 4. The virulence gene identification and antibiotic resistance patterns of every single MRSA isolate.

\begin{tabular}{|c|c|c|c|}
\hline Sampling Point & $\begin{array}{c}\text { Numbers of MRSA } \\
\text { Isolates }\end{array}$ & $\begin{array}{c}\text { Detection of } \\
\text { Virulence Genes }\end{array}$ & $\begin{array}{l}\text { Antibiotic } \\
\text { Resistance }\end{array}$ \\
\hline \multirow{5}{*}{ First chicken shed } & 1 & eta & C-CIP-CC-E-T \\
\hline & 2 & eta & C-CIP-CC-E-T \\
\hline & 3 & eta & C-CIP-CC-E-T \\
\hline & 4 & eta & C-CIP-CC-E-T \\
\hline & 5 & eta & C-CIP-CC-E-T \\
\hline \multirow{5}{*}{ Second chicken shed } & 6 & eta, etb & C-CIP-CC-E-T \\
\hline & 7 & eta, etb & C-CIP-CC-E-T \\
\hline & 8 & $e t a, e t b$ & C-CIP-CC-E-T \\
\hline & 9 & eta, etb & C-CIP-CC-T \\
\hline & 10 & eta & C-CIP-CC-E-T \\
\hline \multirow{5}{*}{ Exposure square } & 11 & eta, etb & C-CIP-CC-E-T \\
\hline & 12 & eta, etb & C-CIP-CC-E-T \\
\hline & 13 & eta, etb & C-CIP-CC-E-T \\
\hline & 14 & eta, etb & C-CIP-CC-E-T \\
\hline & 15 & ent $A$, eta & C-CIP-CC-E-T \\
\hline \multirow{3}{*}{$3 \mathrm{~m}$ Downwind } & 16 & eta & C-CIP-CC-E-T \\
\hline & 17 & ent $A$, eta & C-CIP-CC-E-T \\
\hline & 18 & ent $A$, eta & C-CIP-CC-E-T \\
\hline \multirow{2}{*}{$5 \mathrm{~m}$ Downwind } & 19 & ent $A$, eta & C-CIP-CC-E-T \\
\hline & 20 & ent $A$, eta & C-CIP-CC-E-T \\
\hline $20 \mathrm{~m}$ Downwind & ND & ND & ND \\
\hline $50 \mathrm{~m}$ Downwind & 21 & ent $A$, eta & C-CIP-CC-E-T \\
\hline $50 \mathrm{~m}$ Upwind & ND & ND & ND \\
\hline
\end{tabular}

\subsection{Antimicrobial Property and Multidrug Resistance Pattern of Isolated MRSA Clones}

The results of the antimicrobial susceptibility test against eight selected antibiotics (clindamycin, gentamicin, sulfamethoxazole-trimethoprim, chloramphenicol, tetracycline, erythromycin, ciprofloxacin, rifampicin) on 21 MRSA isolates of this study are shown in Tables 4 and 5. According to the diameter of the zone of inhibition, all MRSA isolates from chicken shed indoor air, the exposure area and downwind $(3,5$ and $50 \mathrm{~m})$ distance bioaerosol samples were resistant to chloramphenicol, ciprofloxacin, clindamycin, and tetracycline. At the same time, $95.23 \%$ of total isolates were resistant to erythromycin. However, none of them were resistant to gentamicin, rifampicin, and sulfamethoxazoletrimethoprim. Detailed standard scores for the zone of inhibition diameter measurements to determine the resistance in MRSA isolates are shown in supplementary Table S4. A total of twenty isolates showed the MDR pattern belonging to five groups of antibiotics (C-CIP-CC-E-T), and only one isolate displayed the MDR pattern belonging to four groups of antibiotics (C-CIP-CC-T). Overall, all MRSA isolates exhibited multiple drug resistance properties. 
Table 5. The value of zone of inhibition diameter measurements and multiple drug resistance categorization of MRSA isolates.

\begin{tabular}{|c|c|c|c|c|c|c|c|c|c|}
\hline & Chloramphenicol & Ciprofloxacin & Clindamycin & Erythromycin & Gentamicin & Rifampicin & Tetracycline & $\begin{array}{l}\text { Sulfamethoxazole- } \\
\text { Trimethoprim }\end{array}$ & $\begin{array}{c}\text { Multiple Drug } \\
\text { Resistance }\end{array}$ \\
\hline & C & CIP & $\mathrm{CC}$ & $E$ & GM & RA & $\mathrm{T}$ & $\mathrm{S} / \mathrm{T}$ & (MDR) \\
\hline $\begin{array}{l}\text { First chicken shed } \\
\qquad(n=5)\end{array}$ & $\begin{array}{l}\mathrm{R} \\
\mathrm{R} \\
\mathrm{R} \\
\mathrm{R} \\
\mathrm{R}\end{array}$ & $\begin{array}{l}\mathrm{R} \\
\mathrm{R} \\
\mathrm{R} \\
\mathrm{R} \\
\mathrm{R}\end{array}$ & $\begin{array}{l}\mathrm{R} \\
\mathrm{R} \\
\mathrm{R} \\
\mathrm{R} \\
\mathrm{R}\end{array}$ & $\begin{array}{l}\mathrm{R} \\
\mathrm{R} \\
\mathrm{R} \\
\mathrm{R} \\
\mathrm{R}\end{array}$ & $\begin{array}{l}\mathrm{S} \\
\mathrm{S} \\
\mathrm{S} \\
\mathrm{S} \\
\mathrm{S}\end{array}$ & $\begin{array}{l}\mathrm{S} \\
\mathrm{S} \\
\mathrm{S} \\
\mathrm{S} \\
\mathrm{S}\end{array}$ & $\begin{array}{l}\mathrm{R} \\
\mathrm{R} \\
\mathrm{R} \\
\mathrm{R} \\
\mathrm{R}\end{array}$ & $\begin{array}{l}\text { I } \\
\text { I } \\
\text { I } \\
\text { I } \\
\text { I }\end{array}$ & $\begin{array}{l}\text { C-CIP-CC-E-T } \\
\text { C-CIP-CC-E-T } \\
\text { C-CIP-CC-E-T } \\
\text { C-CIP-CC-E-T } \\
\text { C-CIP-CC-E-T }\end{array}$ \\
\hline $\begin{array}{l}\text { Second chicken } \\
\text { shed }(n=5)\end{array}$ & $\begin{array}{l}\mathrm{R} \\
\mathrm{R} \\
\mathrm{R} \\
\mathrm{R} \\
\mathrm{R}\end{array}$ & $\begin{array}{l}\mathrm{R} \\
\mathrm{R} \\
\mathrm{R} \\
\mathrm{R} \\
\mathrm{R}\end{array}$ & $\begin{array}{l}\mathrm{R} \\
\mathrm{R} \\
\mathrm{R} \\
\mathrm{R} \\
\mathrm{R}\end{array}$ & $\begin{array}{l}\mathrm{R} \\
\mathrm{R} \\
\mathrm{R} \\
\mathrm{S} \\
\mathrm{R}\end{array}$ & $\begin{array}{l}\mathrm{S} \\
\mathrm{S} \\
\mathrm{S} \\
\mathrm{S} \\
\mathrm{S}\end{array}$ & $\begin{array}{l}\mathrm{S} \\
\mathrm{S} \\
\mathrm{S} \\
\mathrm{S} \\
\mathrm{S}\end{array}$ & $\begin{array}{l}\mathrm{R} \\
\mathrm{R} \\
\mathrm{R} \\
\mathrm{R} \\
\mathrm{R}\end{array}$ & $\begin{array}{l}\text { I } \\
\text { I } \\
\text { I } \\
\text { S } \\
\text { I }\end{array}$ & $\begin{array}{l}\text { C-CIP-CC-E-T } \\
\text { C-CIP-CC-E-T } \\
\text { C-CIP-CC-E-T } \\
\text { C-CIP-CC-T } \\
\text { C-CIP-CC-E-T }\end{array}$ \\
\hline $\begin{array}{c}\text { Exposure square } \\
(n=5)\end{array}$ & $\begin{array}{l}\mathrm{R} \\
\mathrm{R} \\
\mathrm{R} \\
\mathrm{R} \\
\mathrm{R}\end{array}$ & $\begin{array}{l}\mathrm{R} \\
\mathrm{R} \\
\mathrm{R} \\
\mathrm{R} \\
\mathrm{R}\end{array}$ & $\begin{array}{l}\mathrm{R} \\
\mathrm{R} \\
\mathrm{R} \\
\mathrm{R} \\
\mathrm{R}\end{array}$ & $\begin{array}{l}\mathrm{R} \\
\mathrm{R} \\
\mathrm{R} \\
\mathrm{R} \\
\mathrm{R}\end{array}$ & $\begin{array}{l}\mathrm{S} \\
\mathrm{S} \\
\mathrm{S} \\
\mathrm{S} \\
\mathrm{S}\end{array}$ & $\begin{array}{l}\mathrm{S} \\
\mathrm{S} \\
\mathrm{S} \\
\mathrm{S} \\
\mathrm{S}\end{array}$ & $\begin{array}{l}\mathrm{R} \\
\mathrm{R} \\
\mathrm{R} \\
\mathrm{R} \\
\mathrm{R}\end{array}$ & $\begin{array}{l}\text { S } \\
\text { S } \\
\text { S } \\
\text { I } \\
\text { I }\end{array}$ & $\begin{array}{l}\text { C-CIP-CC-E-T } \\
\text { C-CIP-CC-E-T } \\
\text { C-CIP-CC-E-T } \\
\text { C-CIP-CC-E-T } \\
\text { C-CIP-CC-E-T }\end{array}$ \\
\hline $3 \mathrm{~m}$ Downwind & $\begin{array}{l}\mathrm{R} \\
\mathrm{R} \\
\mathrm{R}\end{array}$ & $\begin{array}{l}\mathrm{R} \\
\mathrm{R} \\
\mathrm{R}\end{array}$ & $\begin{array}{l}\mathrm{R} \\
\mathrm{R} \\
\mathrm{R}\end{array}$ & $\begin{array}{l}\mathrm{R} \\
\mathrm{R} \\
\mathrm{R}\end{array}$ & $\begin{array}{l}\mathrm{S} \\
\mathrm{S} \\
\mathrm{S}\end{array}$ & $\begin{array}{l}\mathrm{S} \\
\mathrm{S} \\
\mathrm{S}\end{array}$ & $\begin{array}{l}\mathrm{R} \\
\mathrm{R} \\
\mathrm{R}\end{array}$ & $\begin{array}{l}\text { I } \\
\text { I } \\
\text { I }\end{array}$ & $\begin{array}{l}\text { C-CIP-CC-E-T } \\
\text { C-CIP-CC-E-T } \\
\text { C-CIP-CC-E-T }\end{array}$ \\
\hline 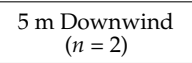 & $\begin{array}{l}\mathrm{R} \\
\mathrm{R}\end{array}$ & $\begin{array}{l}\mathrm{R} \\
\mathrm{R}\end{array}$ & $\begin{array}{l}\mathrm{R} \\
\mathrm{R}\end{array}$ & $\begin{array}{l}\mathrm{R} \\
\mathrm{R}\end{array}$ & $\begin{array}{l}\text { S } \\
S\end{array}$ & $\begin{array}{l}\text { S } \\
S\end{array}$ & $\begin{array}{l}\mathrm{R} \\
\mathrm{R}\end{array}$ & $\begin{array}{l}\text { I } \\
\text { I }\end{array}$ & $\begin{array}{l}\text { C-CIP-CC-E-T } \\
\text { C-CIP-CC-E-T }\end{array}$ \\
\hline $\begin{array}{c}20 \mathrm{~m} \text { Downwind } \\
(n=0)\end{array}$ & ND & ND & ND & ND & ND & ND & ND & ND & ND \\
\hline $\begin{array}{c}50 \mathrm{~m} \text { Downwind } \\
(n=5)\end{array}$ & $\mathrm{R}$ & $\mathrm{R}$ & $\mathrm{R}$ & $\mathrm{R}$ & S & S & $\mathrm{R}$ & I & C-CIP-CC-E-T \\
\hline $\begin{array}{c}\text { 50m Upwind } \\
(n=0)\end{array}$ & ND & ND & ND & ND & ND & ND & ND & ND & ND \\
\hline $\begin{array}{c}\text { Total percentage } \\
\quad(n=21)\end{array}$ & $21(100 \%)$ & $21(100 \%)$ & $21(100 \%)$ & $20(95.23 \%)$ & $0(0 \%)$ & $0(0 \%)$ & $21(100 \%)$ & $0(0 \%)$ & $21(100 \%)$ \\
\hline
\end{tabular}

$\mathrm{R}=$ resistance, $\mathrm{I}=$ intermediate, $\mathrm{S}$ = susceptible; C-CIP-CC-E-T = chloramphenicol-ciprofloxacin-clindamycinerythromycin-tetracycline; C-CIP-CC-T = chloramphenicol-ciprofloxacin-clindamycin-tetracycline; ND = not detected (sample has no MRSA isolates).

\section{Discussion}

Previous studies related to pathogenic microbes highlighted that diverse Grampositive and Gram-negative bacteria such as S. aureus, Escherichia coli, Streptococcus suis, and Actinobacillus pleuropneumoniae are most prevalent in livestock farming bioaerosol samples [23,24]. The loads of viable bacterial colony formation units in this study were much higher in the first and second chicken sheds, and the exposure square area samples than downwind bioaerosol samples, as shown in Table 1. Gibbs et al. [25] reported a similar trend in decreased airborne bacteria CFUs in downwind sampling zones up to $150 \mathrm{~m}$ distance from the swine barn area, which is consistent with our results. Additionally, Liu et al. demonstrated the transmission of $S$. aureus in the air from henhouse indoor to outdoor downwind sampling areas [9]. In this study, the MRSA strain was also isolated from both chicken sheds and downwind sampling points (up to $50 \mathrm{~m}$ ), which is in line with our previous study results [11]. Therefore, it could be suggested that the bioaerosol samples in the present study had adequate potential to carry and transmit the MRSA strains from the chicken shed indoor air to the surrounding downwind ambient environment. In addition, the number of total MRSA isolates colonies was continuously decreased with increasing the sampling distance from the chicken farm indoor environment. According to a previous study, the load of airborne bacteria in indoor and outdoor bioaerosol might vary due to the air exchangeable rate and carbon dioxide concentration of ambient air [26]. Additionally, Homidan et al. [27] have discussed that ammonia concentrations in poultry farm indoor air might be influenced by the poor ventilation system, it may directly reduce the air exchangeable rate of chicken farm indoor environment which help to increase the CFU load in the air. In our study, a similar trend was observed using statistical analysis. For example, the correlation coefficient $(r)$ value showed that the prevalence of MRSA and viable airborne bacteria CFU load was negatively correlated with wind speed and positively correlated with ammonia and methylamine concentrations (Supplementary Table S3). The outdoor bioaerosol sampling area had a high wind speed; therefore, there was an enhanced air exchangeable rate. This factor might elevate more bioaerosol dispersal and negatively impact the CFU 
count of total bacteria, specifically, the MRSA prevalence in outdoor downwind bioaerosol samples (up to $50 \mathrm{~m}$ ) of this study. The Pearson correlation coefficient R-value also showed a negative relationship between the total bacteria count from bioaerosol samples and the distance of sampling point in the downwind area (Supplementary Table S3). This result could elaborate that in an outdoor environment, increasing the sampling distance might positively influence the air exchangeable rate. As the air exchangeable rate increases, it can downregulate the CFU load. Additionally, the occurrence of ammonia and methylamine may be associated with the CFU count of airborne bacteria and MRSA load in chicken sheds and exposure area bioaerosol samples of this study [28].

Butaye et al. [24] have described that the SCCmec (type III, IV and V) containing LA-MRSA (CC9 strain) are mainly found from different livestock units of many Asian countries such as Thailand, China, Hong Kong, Malaysia, Taiwan, and South Korea. All the isolated MRSA isolates from eight bioaerosol samples of this study carried the SCCmec type VIII elements and belonged to hospital-associated MRSA group. This finding is in line with the previous study results of bioaerosol samples associated with chicken farm environments [11]. Funaki et al. [29] demonstrated that SCCmec type VIII could also be found in community harbored MRSA strains. An Asia-specific report highlighted that most HA-MRSA isolates in Taiwan carried SCCmec elements type IV and III [30]. The identified SCCmec type VIII element bearing MRSA isolates in this study possibly belonged to a new lineage of epidemic MRSA strain, according to the International Working Group on the Classification of Staphylococcal Cassette Chromosome Elements (IWG-SCC). The existence of SCCmec type VIII element in MRSA strains was initially reported in Canada, and it was also later found in the United States [31,32]. Additionally, a previous report revealed that spa type 002 was one of the most prevalent MRSA strains in Asia, Europe, and America [33]. In this present study, all the MRSA isolates belonged to the 002 spa type, which is consistent with the results of past studies from bioaerosols and environmental samples associated with chicken and swine farming areas [11,34]. Therefore, we suggest that MRSA isolates in the air samples associated with indoor and outdoor downwind (up to $50 \mathrm{~m}$ ) chicken farm areas in this study have enough potential to causes outbreaks of epidemic nosocomial infection in the surrounding environment via bioaerosol transmission.

MRSA constitutes several virulence factors that determine the severity of their pathogenesis in the target host. Among several virulence factors, such as exotoxin, enterotoxin, and exfoliative toxin-encoding genes only the eta was positive for all the isolates of this study. In contrast, $38.09 \%$ and $23.80 \%$ of total isolates were positive for the etb and ent $A$ genes. A past study showed $100 \%$ and $70.2 \%$ detection rates of et $a$ and $e t b$ genes all over the MRSA isolates from poultry farm bioaerosol samples, respectively, which is consistent with the results of the present study [11]. However, Szafraniec et al. [35] demonstrated that most exfoliative toxin $A$ gene infections in chickens were related to Staphylococcus hyicus. Pathogenicity by exfoliative toxin genes eta and etb had much greater severity on the human body by stimulating skin peeling and the blistering development in the host cell [36-38]. However, these exfoliative toxin genes, eta and etb, could also develop staphylococcal pathogenicity on other livestock bodies, e.g., porcine [39]. Additionally, enterotoxin gene A (ent A) detection in this study could highlight that the MRSA isolates might have the potential to produce a high level of super antigenic activity, such as through inflammatory cytokines via the disruption of adaptive immunity through stimulating $\mathrm{T}$ cells [40]. Thus, we suggest that infected hosts might face the severe pathogenicity of MRSA during staphylococcal outbreaks from chicken farm bioaerosols to adjacent air.

Due to the misuse and overuse of various antibiotics, resident microorganisms in livestock farming may acquire antimicrobial resistance properties via selective pressure [41]. Past studies on antibiotic resistance associated with airborne microbes from livestock farming areas had described that tetracycline- and erythromycin-resistant $S$. aureus was the most prevalent pathogenic bacteria in this environment, posing a serious risk to public health $[41,42]$. In this study, $100 \%$ and $95.23 \%$ of the total MRSA isolates from chicken farm indoor and outdoor samples were resistant to chloramphenicol, ciprofloxacin, clindamycin, 
tetracycline, and erythromycin. At the same time, all of them exhibited multiple drug resistance properties based on the disk diffusion method. In this context, Tao et al. [11] have observed a similar antibiotic resistance pattern in MRSA isolates associated with chicken farm bioaerosol samples, which is consistent with the present study. Similarly, Liu et al. [9] demonstrated that $S$. aureus transmission via bioaerosol from an indoor poultry farm environment to downwind air was resistant to sulfamethoxazole, penicillin, tetracycline, chloramphenicol and erythromycin, which also supports our study results. Additionally, the molecular characterization of MRSA isolates following the chi-squared statistical test revealed that all 21 isolates from each sampling area were genotypically associated with each other (Supplementary Table S5). Therefore, the current investigation demonstrates a multidrug-resistant MRSA strain population that could be an emerging epidemiological risk near chicken farms, which warrants thorough pathogen management and control measures.

\section{Materials and Methods}

\subsection{Sampling Information and Site Description}

The sampling site of this present study was in Dalin county of southern Taiwan. The primary objective of this sampling was to survey the pattern of MRSA colonies spread out from the chicken farm indoor environment to the outdoor environment via bioaerosol transmission and including their molecular typing. A total of 8 bioaerosol samples were collected from two adjacent chicken sheds inside, one exposure square (an empty place between these two chicken sheds), one upwind and four downwind (up to $50 \mathrm{~m}$ ) area's ambient air. Geographical coordinates of each sampling point have been described in supplementary Table S1. The procedure of bioaerosol samples collection was done by following the previous study's standardized protocol of bioaerosol collection [11]. Figure 1 shows the overview of the bioaerosol sampling strategy and molecular typing of MRSA isolates.

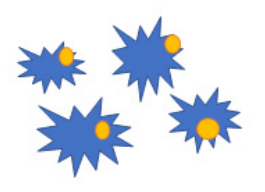

\section{Bioaerosol Sampling}
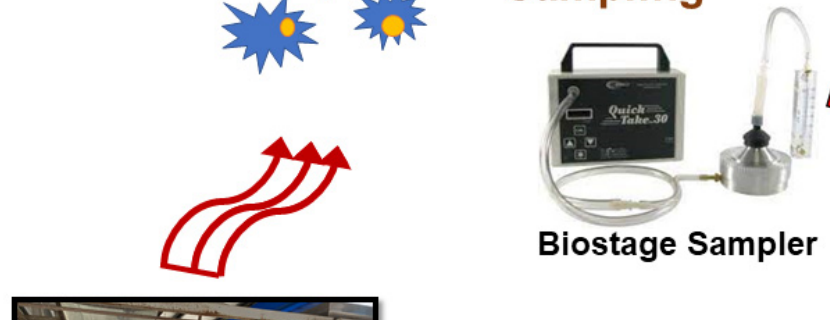

\section{Biostage Sampler}

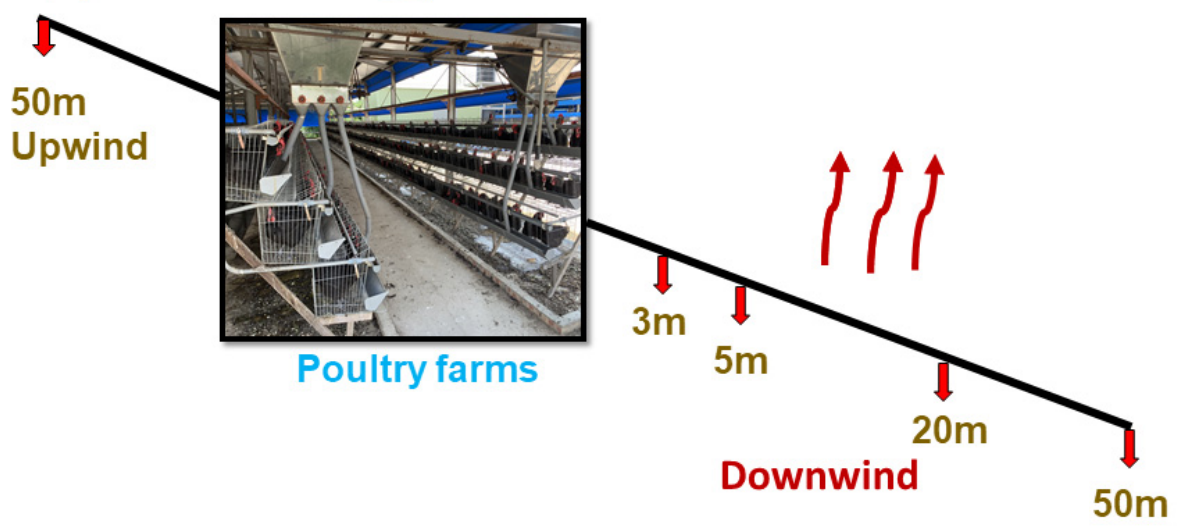

\section{MRSA-transmission on poultry bioaerosols}
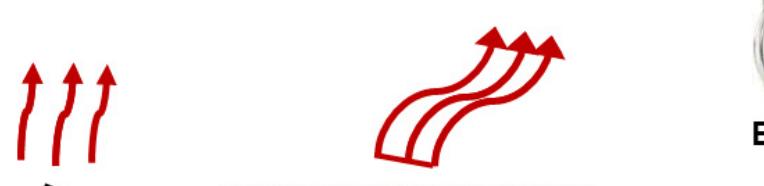
with $100 \mathrm{mg} / \mathrm{mL}$ cycloheximide was used according to a prior study protocol to count the overall bacteria colony formation unit per volume of air samples (meter cubed) [11,43]. The direction and speed of the wind were detected using a digital anemometer (Puxicoo P6-8232). Additionally, the concentrations of ammonia, mercaptans, methylamine, and hydrogen sulfide in the surrounding ambient air was measured to show the odor production by the chicken shed. A gas detector system and detection tubes (Gastec Inc., Fukayanaka, Japan) were used to measure the concentration of these gaseous compounds in the ambient air, according to the instructions of the company provided in the operating manual (https: / /www.gastec.co.jp/en/instructionmanual, accessed on 6 June 2020).

\subsection{Isolation and Culture of MRSA Isolates from Bioaerosol Samples}

After sampling the CHROMagar ${ }^{\mathrm{TM}}$ MRSA was pulled out from the BioStage sampler and directly inserted into an incubator at $37^{\circ} \mathrm{C}$ for $24 \mathrm{~h}$ to let the MRSA colony grow properly. Next, to isolate the MRSA in pure culture, the mauve color grown colony was picked up and put into brain-heart infusion broth (BHIB) media following incubation at $37^{\circ} \mathrm{C}$ temperature for $24 \mathrm{~h}$. Again, one loop of BHIB was taken up and streaked on a Baird-Parker agar plate following incubation at $37^{\circ} \mathrm{C}$ for $24 \mathrm{~h}$. Finally, a pure single MRSA colony was inoculated into BHIB and grown for $24 \mathrm{~h}$ at $37^{\circ} \mathrm{C}$. The next day, the grown culture of MRSA was preserved in $33 \%$ glycerol at $-20{ }^{\circ} \mathrm{C}$. Later, this pure cultured broth was used for DNA extraction.

\subsection{Molecular Typing of MRSA Isolates}

Genomic DNA of MRSA was extracted using a commercial DNA extraction kit (MagPurix Bacterial DNA Extraction Kit, ZP02006), following the protocol described in previous studies $[2,11]$. After that, different molecular typing experiments were performed via PCR analysis to characterize the MRSA isolates. Briefly, Nuc and mecA gene sequence was amplified to confirm the isolated colonies from samples belonging to MRSA strain. SCCmec element and the panton-valentine leukocidine $(P V L)$ gene were targeted to categorize MRSA isolates. Three toxin genes, including exfoliative toxins (eta and etb), enterotoxins (ent $A$ to $E$ ), and exotoxin gene toxic shock syndrome toxin-1 (tsst-1), were targeted to determine their virulence factors. Additionally, in this study, spa typing was conducted using commercial software (BioNumerics) to describe the epidemiological aspect of MRSA isolates. The primers sequences used to identify these genes, along with the respective PCR reaction protocols, have been provided in supplementary Table S2. Electrophoresis analysis was performed on $1.5 \%$ agarose gel at $110 \mathrm{~V}$ for $30 \mathrm{~min}$ to confirm the presence of the respective PCR product in each PCR amplification.

\subsection{Anti-Microbial Susceptibility Test}

A total of 8 antibiotics-clindamycin (DA, $2 \mu \mathrm{g})$, gentamicin (G, $10 \mu \mathrm{g})$, sulfamethoxazoletrimethoprim (S/T, 23.75/1.75 $\mu \mathrm{g})$, chloramphenicol (C, $30 \mu \mathrm{g})$, tetracycline (T, $30 \mu \mathrm{g})$, erythromycin (E, $15 \mu \mathrm{g}$ ), ciprofloxacin (CIP, $5 \mu \mathrm{g}$ ), and rifampicin (RA, $5 \mu \mathrm{g}$ ) -were selected to determine the antimicrobial resistance properties of MRSA isolates using the disk diffusion method, as described previously [11,44]. The multidrug resistance pattern of MRSA isolates was categorized as previously described by Magiorakos et al. [45]. A standard score of the zones of inhibition diameter of reported antibiotic-resistant strain has been shown in Supplementary Table S4, which was used to characterize the antibiotic resistance of MRSA isolates. The standard scores of the zones of inhibition diameters for the applied antibiotics were determined according to the documents from the Clinical \& Laboratory Standards Institute (CLSI) [46].

\subsection{Statistical Analysis}

After checking the linear distribution of the data, Pearson correlation analysis was performed to determine the impact of environmental parameters on the load of airborne bacteria colony count using SPSS software (IBM SPSS statistics 24). The chi-squared test 
was also performed with SPSS software to prove the distributional relationship between MRSA isolates from indoor and outdoor chicken farm bioaerosol samples.

\section{Conclusions}

The indoor environment of the chicken sheds of this study could propagate the airborne bacteria, wherein MRSA colonies could spread out from chicken sheds indoor to outdoor environments via bioaerosol transmission. The wind speed and direction may determine their dispersal patterns in the ambient air of chicken farms. At this point, the MRSA colonies from the indoor chicken shed environments were mostly transmitted to the exposure square and downwind areas of chicken sheds. Our strain characterization results highlighted that all the MRSA isolates contained SCCmec element type VIII and fitted into spa type t002 and hospital-harbored MRSA strain. All (100\%) of the isolates carried exfoliative toxin gene A (eta), 38.09\% carried exfoliative toxin gene B (etb), and $23.80 \%$ carried enterotoxin gene class $\mathrm{A}(e n t A)$. These isolates possess drug resistance properties against chloramphenicol, ciprofloxacin, clindamycin, tetracycline, and erythromycin. The findings of this study highlighted strong evidence on MRSA strain transmission from chicken sheds indoor air to downwind outdoor air. In addition, the molecular typing results underpinned the elevated epidemiological risk by exposing humans and livestock to pathogenic hospital-associated MRSA. Multi-drug resistance characteristics of MRSA isolates could trigger a devastating nearby-community level human as well as the livestock health risk that could be difficult to control.

Supplementary Materials: The following are available online at https:/ / www.mdpi.com/article / 10.3390/antibiotics11010081/s1, Table S1. The details of bioaerosol sampling of chicken farm environment; Table S2. MRSA strain identification, Spa typing, SCCmec typing, and virulence factors detecting genes primers list and PCR conditions; Table S3. Pearson correlation coefficient (r) value and level of significant for environmental parameters and total bacteria count; Table S4. Standard score of zone of inhibition diameter measurements in the disk diffusion method to determine the microbial resistance properties; Table S5. The results of chi-squared tests between sampling point with MRSA strain characterization. References [47-53] are citied in the Supplementary Materials.

Author Contributions: Conceptualization, B.-M.H., J.-S.C. and H.-C.T.; Methodology, S.K., H.-C.T., V.N. and J.-S.C.; Software, H.-C.T., V.N. and J.-S.C.; Validation, J.-S.C. and B.-M.H.; Formal Analysis, B.-M.H., J.-S.C. and H.-C.T.; Investigation, S.K., J.-S.C. and V.N.; Resources, B.-M.H. and S.K.; Data Curation, J.-S.C., H.-C.T. and S.K.; Writing-Original Draft Preparation, S.K., B.-M.H. and G.-J.H.; Writing-Review and Editing, B.-M.H. and H.-C.T.; Visualization, G.-J.H., V.N. and H.-C.T.; Supervision, B.-M.H., S.K. and J.-S.C.; Project Administration, B.-M.H. and H.-C.T.; Funding Acquisition, B.-M.H. and H.-C.T. All authors have read and agreed to the published version of the manuscript.

Funding: This research was supported by the Ministry of Science and Technology of Taiwan (MOST 108-2116-M-194-005 and 109-2116-M-194 -013) and the Buddhist Tzu Chi Hospital (TCRD109-68; TCRD110-44). This research was also supported by Ditmanson Medical Foundation Chia-Yi Christian Hospital.

Institutional Review Board Statement: Not applicable.

Informed Consent Statement: Not applicable.

Data Availability Statement: The data presented in this study are available on request from the corresponding author.

Acknowledgments: The authors are grateful to Cheng-Siou Li for their technical support.

Conflicts of Interest: The authors declare no conflict of interest. 


\section{References}

1. Yang, Y.; Zhou, R.; Chen, B.; Zhang, T.; Hu, L.; Zou, S. Characterization of airborne antibiotic resistance genes from typical bioaerosol emission sources in the urban environment using metagenomic approach. Chemosphere 2018, 213, 463-471. [CrossRef] [PubMed]

2. Hsu, B.-M.; Chen, J.-S.; Lin, I.-C.; Hsu, G.-J.; Koner, S.; Hussain, B.; Huang, S.-W.; Tsai, H.-C. Molecular and Anti-Microbial Resistance (AMR) Profiling of Methicillin-Resistant Staphylococcus aureus (MRSA) from Hospital and Long-Term Care Facilities (LTCF) Environment. Antibiotics 2021, 10, 748. [CrossRef]

3. Stetzenbach, L.D. Airborne Infectious Microorganisms. In Encyclopedia of Microbiology, 3rd ed.; Schaechter, M., Ed.; Academic Press: Oxford, UK, 2009; pp. 175-182. [CrossRef]

4. Pearson, C.; Littlewood, E.; Douglas, P.; Robertson, S.; Gant, T.W.; Hansell, A.L. Exposures and Health Outcomes in Relation to Bioaerosol Emissions from Composting Facilities: A Systematic Review of Occupational and Community Studies. J. Toxicol. Environ. Health Part B 2015, 18, 43-69. [CrossRef] [PubMed]

5. Chen, Q.; Hildemann, L.M. The Effects of Human Activities on Exposure to Particulate Matter and Bioaerosols in Residential Homes. Environ. Sci. Technol. 2009, 43, 4641-4646. [CrossRef] [PubMed]

6. Kabelitz, T.; Biniasch, O.; Ammon, C.; Nübel, U.; Thiel, N.; Janke, D.; Swaminathan, S.; Funk, R.; Münch, S.; Rösler, U. Particulate matter emissions during field application of poultry manure-The influence of moisture content and treatment. Sci. Total Environ. 2021, 780, 146652. [CrossRef]

7. Mubareka, S.; Groulx, N.; Savory, E.; Cutts, T.; Theriault, S.; Scott, J.A.; Roy, C.J.; Turgeon, N.; Bryce, E.; Astrakianakis, G.; et al. Bioaerosols and Transmission, a Diverse and Growing Community of Practice. Front. Public Health 2019, 7, 23. [CrossRef]

8. Kim, K.-H.; Kabir, E.; Jahan, S.A. Airborne bioaerosols and their impact on human health. J. Environ. Sci. 2018, 67, 23-35. [CrossRef]

9. Liu, D.; Chai, T.; Xia, X.; Gao, Y.; Cai, Y.; Li, X.; Miao, Z.; Sun, L.; Hao, H.; Roesler, U.; et al. Formation and transmission of Staphylococcus aureus (including MRSA) aerosols carrying antibiotic-resistant genes in a poultry farming environment. Sci. Total Environ. 2012, 426, 139-145. [CrossRef] [PubMed]

10. Kozajda, A.; Jeżak, K.; Kapsa, A. Airborne Staphylococcus aureus in different environments-A review. Environ. Sci. Pollut. Res. 2019, 26, 34741-34753. [CrossRef]

11. Tao, C.-W.; Chen, J.-S.; Hsu, B.-M.; Koner, S.; Hung, T.-C.; Wu, H.-M.; Rathod, J. Molecular Evaluation of Traditional Chicken Farm-Associated Bioaerosols for Methicillin-Resistant Staphylococcus aureus Shedding. Antibiotics 2021, 10, 917. [CrossRef]

12. Kumar, P.; Goel, A.K. Prevalence of Methicillin Resistant Staphylococcal Bioaerosols in and around Residential Houses in an Urban Area in Central India. J. Pathog. 2016, 2016, 7163615. [CrossRef]

13. Anjum, M.F.; Marco-Jimenez, F.; Duncan, D.; Marín, C.; Smith, R.P.; Evans, S.J. Livestock-Associated Methicillin-Resistant Staphylococcus aureus from Animals and Animal Products in the UK. Front. Microbiol. 2019, 10, 2136. [CrossRef]

14. Chongtrakool, P.; Ito, T.; Ma, X.X.; Kondo, Y.; Trakulsomboon, S.; Tiensasitorn, C.; Jamklang, M.; Chavalit, T.; Song, J.-H.; Hiramatsu, K. Staphylococcal cassette chromosome mec (SCCmec) typing of methicillin-resistant Staphylococcus aureus strains isolated in 11 Asian countries: A proposal for a new nomenclature for SCCmec elements. Antimicrob. Agents Chemother. 2006, 50, 1001-1012. [CrossRef]

15. Hashemizadeh, Z.; Hadi, N.; Mohebi, S.; Kalantar-Neyestanaki, D.; Bazargani, A. Characterization of SCCmec, spa types and Multi Drug Resistant of methicillin-resistant Staphylococcus aureus isolates among inpatients and outpatients in a referral hospital in Shiraz, Iran. BMC Res. Notes 2019, 12, 614. [CrossRef] [PubMed]

16. Alkharsah, K.R.; Rehman, S.; Alnimr, A.; Diab, A.; Hawwari, A.; Tokajian, S. Molecular typing of MRSA isolates by spa and PFGE. J. King Saud Univ. Sci. 2019, 31, 999-1004. [CrossRef]

17. Xie, Y.; He, Y.; Gehring, A.; Hu, Y.; Li, Q.; Tu, S.-I.; Shi, X. Genotypes and toxin gene profiles of Staphylococcus aureus clinical isolates from China. PLoS ONE 2011, 6, e28276. [CrossRef] [PubMed]

18. Zomer, T.P.; Wielders, C.C.H.; Veenman, C.; Hengeveld, P.; van der Hoek, W.; de Greeff, S.C.; Smit, L.A.M.; Heederik, D.J.; Yzermans, C.J.; Bosch, T.; et al. MRSA in persons not living or working on a farm in a livestock-dense area: Prevalence and risk factors. J. Antimicrob. Chemother. 2016, 72, 893-899. [CrossRef] [PubMed]

19. Fertner, M.; Pedersen, K.; Jensen, V.F.; Larsen, G.; Lindegaard, M.; Hansen, J.E.; Chriél, M. Within-farm prevalence and environmental distribution of livestock-associated methicillin-resistant Staphylococcus aureus in farmed mink (Neovison vison). Vet. Microbiol. 2019, 231, 80-86. [CrossRef] [PubMed]

20. Kalupahana, R.S.; Duim, B.; Verstappen, K.M.; Gamage, C.D.; Dissanayake, N.; Ranatunga, L.; Graveland, H.; Wagenaar, J.A MRSA in Pigs and the Environment as a Risk for Employees in Pig-Dense Areas of Sri Lanka. Front. Sustain. Food Syst. $2019,3,25$. [CrossRef]

21. Lu, Y.; Lu, Q.; Cheng, Y.; Wen, G.; Luo, Q.; Shao, H.; Zhang, T. High concentration of coagulase-negative staphylococci carriage among bioaerosols of henhouses in Central China. BMC Microbiol. 2020, 20, 1-9. [CrossRef]

22. Friese, A.; Schulz, J.; Zimmermann, K.; Tenhagen, B.-A.; Fetsch, A.; Hartung, J.; Rösler, U. Occurrence of Livestock-Associated Methicillin-Resistant Staphylococcus aureus in Turkey and Broiler Barns and Contamination of Air and Soil Surfaces in Their Vicinity. Appl. Environ. Microbiol. 2013, 79, 2759-2766. [CrossRef]

23. Anderson, B.D.; Lednicky, J.A.; Torremorell, M.; Gray, G.C. The Use of Bioaerosol Sampling for Airborne Virus Surveillance in Swine Production Facilities: A Mini Review. Front. Vet. Sci. 2017, 4, 121. [CrossRef] [PubMed] 
24. Butaye, P.; Argudín, M.A.; Smith, T.C. Livestock-Associated MRSA and Its Current Evolution. Curr. Clin. Microbiol. Rep. 2016, 3 , 19-31. [CrossRef]

25. Gibbs, S.G.; Green, C.F.; Tarwater, P.M.; Mota, L.C.; Mena, K.D.; Scarpino, P.V. Isolation of Antibiotic-Resistant Bacteria from the Air Plume Downwind of a Swine Confined or Concentrated Animal Feeding Operation. Environ. Health Perspect. 2006, 114, 1032-1037. [CrossRef] [PubMed]

26. Huang, H.-L.; Lee, M.-K.; Shih, H.-W. Assessment of Indoor Bioaerosols in Public Spaces by Real-Time Measured Airborne Particles. Aerosol Air Qual. Res. 2017, 17, 2276-2288. [CrossRef]

27. Homidan, A.A.; Robertson, J.F.; Petchey, A.M. Review of the effect of ammonia and dust concentrations on broiler performance. World's Poult. Sci. J. 2007, 59, 340-349. [CrossRef]

28. Zhao, Y.; Zhao, D.; Ma, H.; Liu, K.; Atilgan, A.; Xin, H. Environmental assessment of three egg production systems-Part III: Airborne bacteria concentrations and emissions. Poult. Sci. 2016, 95, 1473-1481. [CrossRef]

29. Funaki, T.; Yasuhara, T.; Kugawa, S.; Yamazaki, Y.; Sugano, E.; Nagakura, Y.; Yoshida, K.; Fukuchi, K. SCCmec typing of PVL-positive community-acquired Staphylococcus aureus (CA-MRSA) at a Japanese hospital. Heliyon 2019, 5, e01415. [CrossRef]

30. Chen, C.J.; Huang, Y.C. New epidemiology of Staphylococcus aureus infection in Asia. Clin. Microbiol. Infect. 2014, 20, 605-623. [CrossRef]

31. Zhang, K.; McClure, J.-A.; Elsayed, S.; Conly, J.M. Novel staphylococcal cassette chromosome mec type, tentatively designated type VIII, harboring class A mec and type $4 \mathrm{ccr}$ gene complexes in a Canadian epidemic strain of methicillin-resistant Staphylococcus aureus. Antimicrob. Agents Chemother. 2009, 53, 531-540. [CrossRef]

32. Chen, L.; Mediavilla, J.R.; Oliveira, D.C.; Willey, B.M.; De Lencastre, H.; Kreiswirth, B.N. Multiplex real-time PCR for rapid staphylococcal cassette chromosome mec typing. J. Clin. Microbiol. 2009, 47, 3692-3706. [CrossRef]

33. Asadollahi, P.; Farahani, N.N.; Mirzaii, M.; Khoramrooz, S.S.; van Belkum, A.; Asadollahi, K.; Dadashi, M.; Darban-Sarokhalil, D. Distribution of the Most Prevalent Spa Types among Clinical Isolates of Methicillin-Resistant and -Susceptible Staphylococcus aureus around the World: A Review. Front. Microbiol. 2018, 9, 163. [CrossRef]

34. Frana, T.S.; Beahm, A.R.; Hanson, B.M.; Kinyon, J.M.; Layman, L.L.; Karriker, L.A.; Ramirez, A.; Smith, T.C. Isolation and Characterization of Methicillin-Resistant Staphylococcus aureus from Pork Farms and Visiting Veterinary Students. PLoS ONE 2013, 8, e53738. [CrossRef] [PubMed]

35. Szafraniec, G.M.; Szeleszczuk, P.; Dolka, B. A Review of Current Knowledge on Staphylococcus agnetis in Poultry. Animals 2020, 10, 1421. [CrossRef] [PubMed]

36. Bukowski, M.; Wladyka, B.; Dubin, G. Exfoliative Toxins of Staphylococcus aureus. Toxins 2010, 2, 1148-1165. [CrossRef]

37. Becker, K.; Friedrich Alexander, W.; Lubritz, G.; Weilert, M.; Peters, G.; von Eiff, C. Prevalence of Genes Encoding Pyrogenic Toxin Superantigens and Exfoliative Toxins among Strains of Staphylococcus aureus Isolated from Blood and Nasal Specimens. J. Clin. Microbiol. 2003, 41, 1434-1439. [CrossRef]

38. Oliveira, D.; Borges, A.; Simões, M. Staphylococcus aureus Toxins and Their Molecular Activity in Infectious Diseases. Toxins 2018, 10, 252. [CrossRef] [PubMed]

39. Gómez-Sanz, E.; Torres, C.; Lozano, C.; Fernandez-Perez, R.; Aspiroz, C.; Ruiz-Larrea, F.; Zarazaga, M. Detection, molecular characterization, and clonal diversity of methicillin-resistant Staphylococcus aureus CC398 and CC97 in Spanish slaughter pigs of different age groups. Foodborne Pathog. Dis. 2010, 7, 1269-1277. [CrossRef] [PubMed]

40. Ortega, E.; Abriouel, H.; Lucas, R.; Gálvez, A. Multiple Roles of Staphylococcus aureus Enterotoxins: Pathogenicity, Superantigenic Activity, and Correlation to Antibiotic Resistance. Toxins 2010, 2, 2117-2131. [CrossRef]

41. Yang, F.; Gao, Y.; Zhao, H.; Li, J.; Cheng, X.; Meng, L.; Dong, P.; Yang, H.; Chen, S.; Zhu, J. Revealing the distribution characteristics of antibiotic resistance genes and bacterial communities in animal-aerosol-human in a chicken farm: From One-Health perspective. Ecotoxicol. Environ. Saf. 2021, 224, 112687. [CrossRef]

42. Chen, M.; Qiu, T.; Sun, Y.; Song, Y.; Wang, X.; Gao, M. Diversity of tetracycline- and erythromycin-resistant bacteria in aerosols and manures from four types of animal farms in China. Environ. Sci. Pollut. Res. 2019, 26, 24213-24222. [CrossRef]

43. Huang, P.-Y.; Shi, Z.-Y.; Chen, C.-H.; Den, W.; Huang, H.-M.; Tsai, J.-J. Airborne and Surface-Bound Microbial Contamination in Two Intensive Care Units of a Medical Center in Central Taiwan. Aerosol Air Qual. Res. 2013, 13, 1060-1069. [CrossRef]

44. Jorgensen, J.H.; Hindler, J.F.; Reller, L.B.; Weinstein, M.P. New Consensus Guidelines from the Clinical and Laboratory Standards Institute for Antimicrobial Susceptibility Testing of Infrequently Isolated or Fastidious Bacteria. Clin. Infect. Dis. 2007, 44, 280-286. [CrossRef]

45. Magiorakos, A.P.; Srinivasan, A.; Carey, R.B.; Carmeli, Y.; Falagas, M.E.; Giske, C.G.; Harbarth, S.; Hindler, J.F.; Kahlmeter, G.; Olsson-Liljequist, B.; et al. Multidrug-resistant, extensively drug-resistant and pandrug-resistant bacteria: An international expert proposal for interim standard definitions for acquired resistance. Clin. Microbiol. Infect. 2012, 18, 268-281. [CrossRef]

46. Clinical and Laboratory Standards Institute. S. Performance Standards for Antimicrobial Susceptibility Testing; Clinical and Laboratory Standards Institute: Wayne, PA, USA, 2017.

47. Sakoulas, G.; Gold, H.S.; Venkataraman, L.; DeGirolami, P.C.; Eliopoulos, G.M.; Qian, Q. Methicillin-resistant Staphylococcus aureus: Comparison of susceptibility testing methods and analysis of mecA-positive susceptible strains. Journal of clinical microbiology 2001, 39, 3946-3951. [CrossRef]

48. Oliveira, D.C.; de Lencastre, H. Multiplex PCR strategy for rapid identification of structural types and variants of the mec element in methicillin-resistant Staphylococcus aureus. Antimicrob. Agents Chemother. 2002, 46, 2155-2161. [CrossRef] 
49. Zhang, K.; McClure, J.-A.; Elsayed, S.; Louie, T.; Conly, J.M. Novel multiplex PCR assay for characterization and concomitant subtyping of staphylococcal cassette chromosome mec types I to V in methicillin-resistant Staphylococcus aureus. J. Clin. Microbiol. 2005, 43, 5026-5033. [CrossRef] [PubMed]

50. Brakstad, O.G.; Aasbakk, K.; Maeland, J.A. Detection of Staphylococcus aureus by polymerase chain reaction amplification of the nuc gene. J. Clin. Microbiol. 1992, 30, 1654-1660. [CrossRef]

51. Bhowmik, D.; Das, B.J.; Pandey, P.; Chetri, S.; Chanda, D.D.; Bhattacharjee, A. An array of multiplex PCR assays for detection of staphylococcal chromosomal cassette mec (SCCmec) types among staphylococcal isolates. J. Microbiol. Methods 2019, 166, 105733. [CrossRef] [PubMed]

52. Asghar, A.H. Molecular characterization of methicillin-resistant Staphylococcus aureus isolated from tertiary care hospitals. Pak. J. Med. Sci. 2014, 30, 698. [CrossRef]

53. Fooladi, A.A.I.; Ashrafi, E.; Tazandareh, S.G.; Koosha, R.Z.; Rad, H.S.; Amin, M.; Soori, M.; Larki, R.A.; Choopani, A.; Hosseini, H.M. The distribution of pathogenic and toxigenic genes among MRSA and MSSA clinical isolates. Microb. Pathog. 2015, 81, 60-66. [CrossRef] [PubMed] 